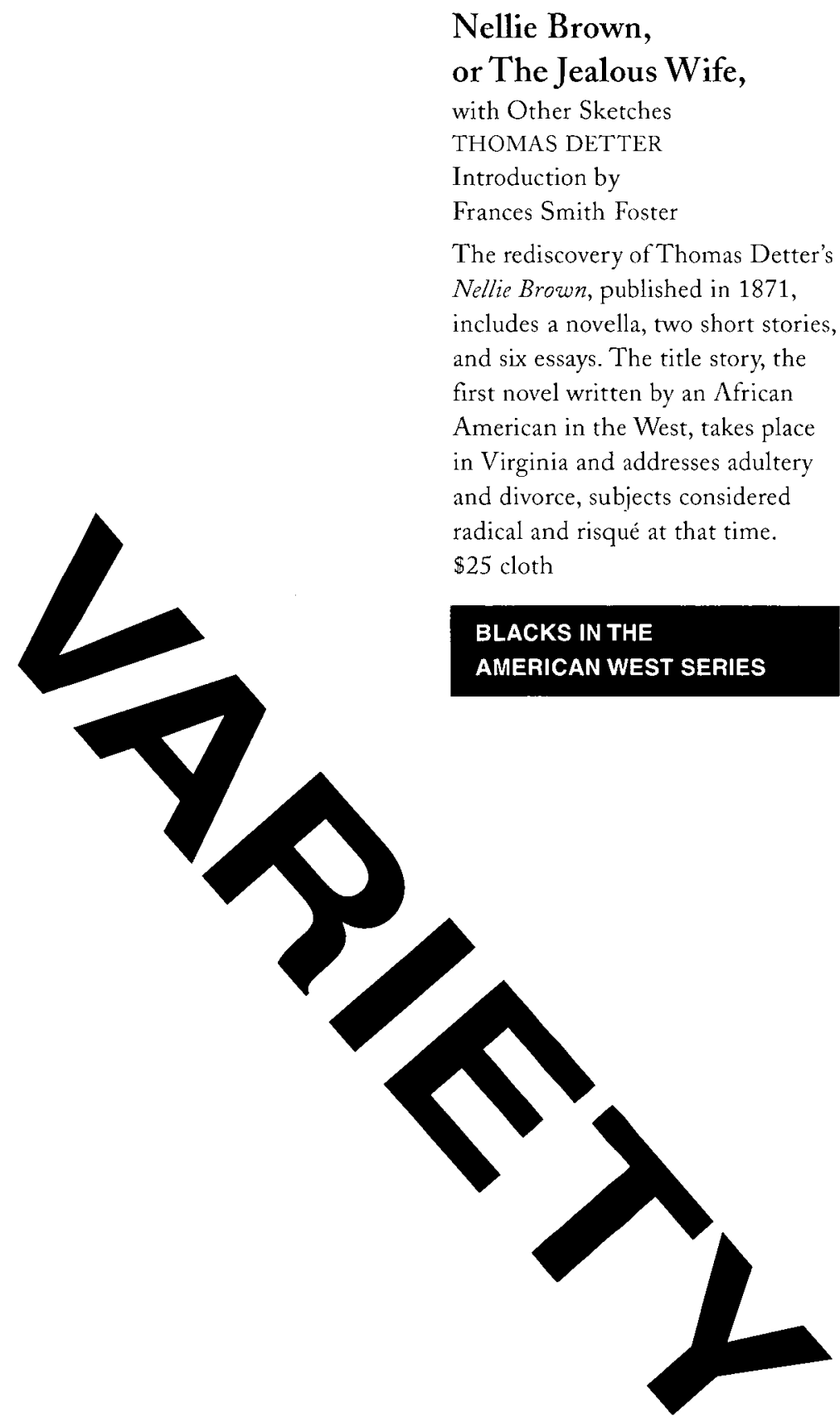

LATIN AMERICAN WOMEN

WRITERS SERIES

\title{
Underground River and
} Other Stories

INÉS ARREDONDO

Translated by Cynthia Steele Foreword by Elena Poniatowska

Inés Arredondo (1928-1989)

published just three slim volumes of stories over twenty-three years, yet her reputation as a great writer is firmly established in Mexico. Her works dwell on obsessions: erotic love, evil, purity, perversion, prostitution, tragic separation, and death.

The stories collected in Underground River and Other Stories focus on female subjectivity and is the first appearance of Arredondo's stories in English. $\$ 12$ paper $\$ 25$ cloth

again in paper On the Historical Novel

(Del romanzo storico) ALESSANDRO MANZONI

Translated with an introduction by Sandra Bermann

"The essay itself and the translator's commentary are valuable to anyone interested in Manzoni, the historical novel, or the criticism of fictional and quasi-fictional modes. Manzoni's essay is concerned with the dilemma created by mixing history with invention." - New York Times Book Review $\$ 10$ paper $\$ 20$ cloth

University of Nebraska Press publishers of Bison Books 312 N 14th Lincoln NE 68588 800-755-1105

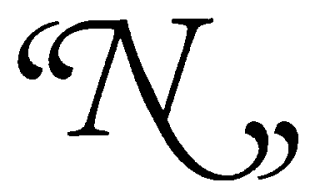




\section{New Literature Titles from Bedford}

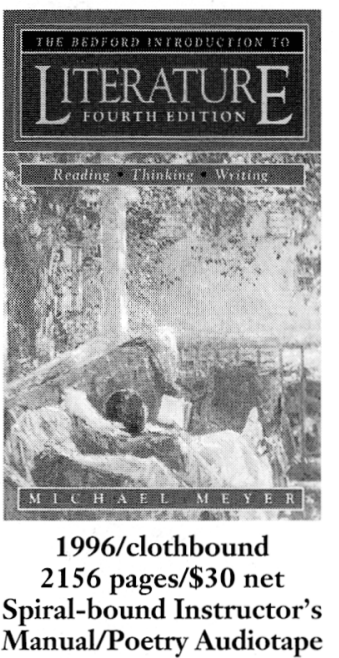

\section{THE BEDFORD INTRODUCTION \\ TO LITERATURE}

Reading, Thinking, and Writing

Fourth Edition

\section{Michael Meyer, University of Connecticut}

new edition of the best-selling 3-genre anthology introduced in the last 10 years 57 stories (15 new), 436 poems (105 new), and 22 plays (6 new) - expanded coverage of writing about literature — integrated throughout with new chapters on writing about fiction, poetry, and drama and 12 sample papers $\boldsymbol{m}$ in-depth coverage of 8 writers, including Langston Hughes (new) - expanded albums of world and contemporary literature $\mathbf{m}$ generous selection of works by women and minority writers 176 (37 new) Perspectives - secondary biographical and critical materials $\mathbf{m}$ strengthened coverage of literary theory throughout $\mathbf{m}$ new glossary of literary terms

- instructor's manual has spiral binding

Now available with any volume in the Case Studies in Contemporary Criticism series at a special price!

New Titles for 1996:

\section{GREAT EXPECTATIONS}

\section{Charles Dickens}

Edited by Janice Carlisle, Tulane University

1996/paper/641 pages

\section{HEART OF DARKNESS}

Joseph Conrad

Second Edition

Edited by Ross C Murfin, University of Miami

1996/paper/304 pages

JANE EYRE

Charlotte Brontë

Edited by Beth Newman, Southern Methodist University

1995/paper/592 pages

\section{THE WIFE OF BATH}

Geoffrey Chaucer

Edited by Peter G. Beidler, Lebigh University 1996/paper/304 pages
Also Available:

WUTHERING HEIGHTS

Emily Brontë

THE AWAKENING

Kate Chopin

GREAT EXPECTATIONS

Charles Dickens

THE SCARLET LETTER

Nathaniel Hawthorne

THE TURN OF THE SCREW

Henry James

THE DEAD

James Joyce

A PORTRAIT OF THE ARTIST

AS A YOUNG MAN

James Joyce

HAMLET

William Shakespeare

FRANKENSTEIN

Mary Shelley

GULLIVER'S TRAVELS

Jonathan Swift

THE HOUSE OF MIRTH

Edith Wharton

\section{BEDFORD BOOKS of St. Martin's Press For exam copies, call 1-800-446-8923}

